\title{
PREVENTING RELIGIOUS PERSECUTION AGAINST AHMADIYAH
}

\author{
Ahmad Afnan Anshori, MA. \\ IAIN Walisongo Semarang \\ afnan_anshori@walisongo.ac.id
}

\begin{abstract}
As a global phenomenon, religious persecution might occur within all religions as well as nations. In Indonesia, this phenomenon occurs within Islam. One of the most controversial cases regarding religious persecution is the discrimination experienced by Ahmadiyah. Here, they could not perform religious activeties freely as they are prohibited to do so. In addition, their properties as well as their religious and educational facilities have been destroyed. To resolve this case, there are at least, two approaches that can be used, which include judicial and non-judicial strategies. This research suggests the use of non-judicial strategies, which aim at eradicating religious persecution experienced by Ahmadis by raising people's consciousness about religious tolerance and human rights. This includes intra-religious dialogue and multicultural and human rights education. In terms of dialogue, this research suggests the use of intra-religious dialogue within Islam, especially between Ahmadiyah and orthodox Muslims.
\end{abstract}

Key words: ahmadiyah, religious persecution, intra-religious dialogue, multicultural education

\section{INTRODUCTION}

Religious persecution is a global phenomenon, and refers to a form of discrimination based on intolerance for different religions and beliefs. In some cases, it can occur within one religion or belief (for example between Catholics and Protestants within Christianity or Sunni and Shi'at within Islam). However, it seems that not many people pay attention to such internal persecution, especially those happening within Islam. This can be ceen from the fact that not much recearch has heen done to exnoce thic

TEOLOGIA, VOLUME 23, NOMOR 1, JANUARI 2012 
Islam in Indonesia, especially the persecution against Jemaat Ahmadiyah Indonesia (JAI). Ahmadiyah is a minority Muslim group in Indonesia. Ahmadiyah members are called Ahmadi. There are about 10 million Ahmadis throughout the world, with more than 200,000 Ahmadis living in Indonesia. This form of Islam was founded around 1889 by Mirza Ghulam Ahmad (1835-1908) in Qadian, India. In 1914, this movement had split into two factions, Qadian and Lahore, as the result of different interpretation of the founder's doctrines.

\section{RELIGIOUS PERSECUTION TERMINOLOGY}

It is important to understand the definition of religious persecution from a human rights context, especially with regard to the case of Jemaat Ahmadiyah Indonesia. According to Marshal, religious persecution can be defined as severe discrimination that comes from an individual's faith. In fact, discrimination also stems from collective rights, such as the discrimination of the Ahmadiyah as a religious group. With regard to human rights discourse, discrimination is considered as the denial of one of the human's fundamental rights, that is the right to religious freedom. Furthermore, it is important to note that discrimination will be a complex phenomenon if various factors related to religion, race, gender, class and other factors might be involved. ${ }^{1}$

Based on the above definition, it is likely that the meaning of religious persecution is not the same as the meaning of religious discrimination. Eltayeb for instance, argues that religious discrimination is not broad enough to include religious persecution. Religious discrimination can be defined as any act denying the enjoyment of the freedom of religion in general, whereas 'the term 'religious persecution' is used to describe a particularly serious situation of discrimination where a campaign or program is initiated to harass, intimidate, and punish a group because of its religion and belief. ${ }^{2}$

Based on the above definition, it is obvious that the meaning of religious persecution is broader than religious discrimination. In other words, every form of religious persecution would include religious discrimination; on the contrary, not all forms of religious discrimination would constitute religious persecution. ${ }^{3}$ Examples of religious persecution include the Holocaust and religious persecution of Tibetan Buddhists.

\section{THE HISTORY OF AHMADIYAH}

Ahmadiyah was founded in India in 1889 by Mirza Ghulam Ahmad. 
The name "Ahmadiyah" was derived from the name of its founder, "Ahmad", who claimed to be the recipient of a revelation from God. The purpose of the Ahmadiyah establishment is to reform and renew Islam. ${ }^{4}$ Ahmadiyah followers were called Ahmadis. They claim that Ahmadiyah is not a separate religion, but part of Islam. In sociological terms, Ahmadis are not different from other Muslims in general. They perform the five pillars of Islam: reciting the confession of faith that "there is no God but Allah and Muhammad is the Messenger of Allah", praying five times a day, fasting in the month of Ramadhan, reciting the Qur'an, and undertaking pilgrimages to Mecca if they are able to do so. ${ }^{5}$ However, in terms of theology, Ahmadiah is different from orthodox Islam. Ahmadis believe that further prophets can come after Muhammad, and this belief led to the split of Ahmadiyah into two factions in 1914, known as Ahmadiyah Qadiyan and Lahore.

This split in Ahmadiah was caused by three fundamental differences. Firstly, Qadiyan followers believe that Mirza Ghulam Ahmad is a prophet, while Lahore followers consider him as a reformer only. Secondly, Qadiyan followers also believe that Mirza Ghulam Ahmad refers to "Ahmad" which is mentioned in the Qur'an (61:6), while Lahore followers do not. Thirdly, for Qadiyans, Muslims who do not believe that Mirza Ghulam Ahmad is a prophet would be considered infidels. In Indonesia, the Ahmadiyah Qadian call themselves Jemaat Ahmadiyah Indonesia (JAI), or the Congregation of Ahmadiyah Indonesia, with a central office in Parung, Bogor, West Java province, while the Ahmadiyah Lahore call themselves Gerakan Ahmadiyah Indonesia (GAI), or the Ahmadiyah Movement of Indonesia, with a central office in Yogyakarta. The first focuses its activities on propagation and missionary work, while the second focuses more on education and publication activities. Before the SKB (Joint Ministerial Decree) was issued, the Ahmadiyah Qadian (JAI) faced more challenges in Indonesia. However, since it was issued, both the JAI and GAI have been facing similar challenges from the government, as well as from orthodox Muslims, in Indonesia.

The mission of Ahmadiyah arrived in Indonesia in 1925, brought by Hazrat Maulvi Rahmat Ali. It was Khalifatul Masih II, Hazrat Mirza Bashiruddin Mahmud Ahmad, who sent him to Indonesia because of the request of three Indonesian students studying Islamic studies in Qadian: Zaini Dahlan, Abu Bakar Ayyub, and Ahmad Nuruddin. Hazrat Maulvi Rahmat Ali firstly traveled to Aceh and then to Tapaktuan. In 1926, he went to Padang and established a branch office there in 1929. In 1930, he went to Batavia (currently Jakarta) and established a branch office there in 1932. 
Since that time, several branches around West Java (Jawa Barat) and other areas of Indonesia were established. Currently, there are more than 200 branches throughout Indonesia. Previously, the central office of Ahmadiyah had been in Jakarta since 1935. It moved to Parung, Bogor West Java, in 1987 and has been there since.

The existence of Ahmadiyah in Indonesia is legal according to the existing regulations. It was registered in the Ministry of Justice with legal status registration No JA5/23/137, dated $13^{\text {th }}$ of March 1953. Furthermore, Ahmadiyah Qadian obtained the status of social organization by the issuance of letter No 75/DI/VI/2003. This letter was signed by Director for Relations with Political Institutions, the Ministry of Home Affairs.

\section{THE DOCTRINE OF AHMADIYAH}

There are, at least, three doctrinal aspects distinguishing Ahmadiyah from orthodox Islamic teaching. The first and the main aspect is the doctrine of the finality of the prophethood, called khatam al nubuwwa. ${ }^{6}$ This doctrine consists of three basic principles. Firstly, prophets receive special divine protection; secondly, prophets are perfect and free from sins; and, thirdly, prophethood continues. The first and the second principles are shared between Ahmadiyah and orthodox Muslim. Only the third principle, namely the continuation of prophethood, constitutes a different principle distinguishing it from mainstream orthodox Muslims. This problem also led to the split of Ahmadiyah into two, Qadian and Lahore.

Regarding the idea of prophethood (nubuwwah), Ahmadiyah interpret it differently from the mainstream Islamic interpretation. Ahmadis believe that the prophethood still continues. This means that, after the death of Prophet Muhammad, other prophets continue to emerge until the end of the world. These prophets coming after Prophet Muhammad are called buruzi prophets. They are the prophets who do not bring syariat or new laws. In contrast, the classical interpretation held by orthodox Muslim states that the Prophet Muhammad is the final prophet and there is no prophet after him.

The second difference between Ahmadiyah and mainstream Muslims lies in the idea of the Jesus crucifixion. Ahmadis believe that Jesus Christ was crucified, but did not die on the cross, as the Christians believe. He was taken down from the cross alive, and then brought to Kashmir India until he died there. This is different from orthodox Muslim's view that Jesus Christ was not put onto the cross and killed, but was lifted to heaven alive. So, there is a similarity in both the Ahmadis and orthodox Muslim perspectives of 
Christ's death: that Jesus Christ did not die on the cross (as with the Christian belief in the death, resurrection, and second coming).

The third difference between Ahmadiyah and orthodox Muslim lies in the understanding of the meaning of Jihad in Islam. Jihad is one of the important Islamic teachings, as it is mentioned in the Qur'an as one of the commandments that should be undertaken by all Muslims.

According to the classical interpretation of the Qur'an, Muslims are ordered to perform Jihad for religion by sacrificing their wealth and life. In addition, the Qur'anic verses on Jihad can be categorized into four groups: firstly, those who encourage the call or invitation to Islam using peaceful ways; secondly, those who enjoin fighting to prevent aggression; thirdly, those who enjoin military initiative, except in the four sacred months; and fourthly, those who mandate military initiatives absolutely, whatever the time and place.

According to the classical theory of Qur'anic interpretation, called nash mansuh, the verses revealed earlier can be amended by the later verses. In this context, the verses on the peaceful ways and the use of aggression for defensive purposes only are revealed earlier than the verses on unlimited war against the infidels. Therefore, the classical interpretation maintains one form of jihad requiring unrestricted war. This theory is commonly used by the hard line or fundamentalist Islamic groups to attack other groups that they claim as infidels. They understand Jihad more as physical actions, such as war or military action, rather than peaceful persuasion. For Ahmadiah, military jihad can only be carried out for defensives purposes only. ${ }^{7}$ and this has been very well described by Sivan as follows:

There is only one modern Islamic sect, the Ahmadiyah that explicitly forswears recourse to force for offensive aims, and even limits its defensive use to the protection of Muslim persons and property only. Other modern Islamic thinkers gave explicit priority to the defensive dimension of jihadas has often befitted the de facto situation-but they never jettisoned its offensive dimension altogether. The reasons are obvious: one theological, one more sociological. ${ }^{8}$

In other words, Ahmadiyah rejects the theory of nash mansuh and argues that all verses in the Qur'an must be treated equally. Furthermore, Ahmadiyah argues that the idea of Jihad came into being as a result of dangerous situations happening during the beginning periods of Islam. In this regard, Jihad can be understood as a way to defend Islam from attack. Based on the Ahmadiyah vision of Jihad, it can be understood why Ahmadis focus more on using non-violent ways to spread Islam. The 
Ahmadiyah Lahore, for example, focuses more on education publication activities as forms of Jihad rather than aggressive ways. In addition, Ahmadis never respond to physical attacks with other attacks.

\section{PHASES OF PERSECUTION AGAINST AHMADIYAH}

Ahmadiyah has experienced a long history of persecution, not only in Indonesia, but also in other countries where Muslims are the majority population. This global persecution was triggered, for example, by the World Muslim League's recommendation resulting from its 1974 conference. Based on this recommendation, all Islamic organizations and countries should take action regarding the existence of Ahmadiyah (Qadian). ${ }^{9}$ Following this recommendation, many countries outlawed both factions of Ahmadiyah in their territories without distinguishing between Qadian and Lahore, such as Pakistan, Malaysia and Saudi Arabia. In Indonesia, the Ahmadiyah started being persecuted when, in 1980, the MUI (the Council of Indonesian Ulama) issued the first fatwa concerning Ahmadiyah, declaring that it was off the track and misleading (sesat dan menyesatkan). ${ }^{10}$

In 1981, the label of being an off the track and misleading sect was then strengthened by a letter from the Embassy of Saudi Arabia to the Ministry of Religious Affairs recommending that Ahmadiyah was distorting central doctrine. Three years later (1984), the Ministry of Religious Affairs responded to the letter from the Embassy of Saudi Arabia by issuing another circular letter requesting the Ministry of Justice to reconsider the legal status of Ahmadiyah in Indonesia. The reason was that the Ahmadiah's existence "endangers the order and safety of the state".

In the following years, the Ahmadiah situation did not get any better. It has not only been the government that has persecuted it, but also society has too. Attacks and other forms of physical violence happened to both Ahmadiyah's facilities and its followers. In 2005, violence and threats against Ahmadiah worsened. As a result, several Ahmadiyah facilities were destroyed, including mosques, campuses, houses, etc. (The National Commission of Human Rights 2005).

Furthermore, threats, attacks and other forms of violence against Ahmadiyah have been happening on an ongoing basis until present day. On December 18, 2007, for instance, mobs attacked Ahmadis in Kuningan, West Java, resulting in the destruction of mosques and houses, as well as a number of injured people. On April 16, 2008, Indonesia's Coordinating 
Board for Monitoring Mystical Beliefs in Society (Bakor Pakem) recommended the banning of the Ahmadiyah faith. This recommendation triggered a fresh round of attacks on Ahmadiyah during 2008.

The most recent attack in 2008 happened to activists from the National Alliance for the Freedom of Faith and Religion supporting Ahmadiyah in a peaceful rally on June 1 at the National Monument, Jakarta. The attackers were members of hard line Islamic groups, including the Hizbut Tahrir Indonesia (HTI) and Front Pembela Islam (FPI), who call themselves the Komando Lasykar Islam or Islam Troop Command. They attacked the activists using bamboo, rattan and other sticks, leaving 70 activists with injuries, who were sent to hospital due to this brutal attack.

The climax of the systematic persecution was when the government issued the SKB (Joint Ministerial Decree) on 9 June, 2008, which aims at "freezing" activities of the Ahmadiyah sect. The decree demonstrates how hard line or radical groups, which lack strong political support in Indonesia, have been able to develop lobbies in the bureaucracy and use civil society advocacy techniques to influence government policy.

Surat Keputusan Bersama (SKB), or the Joint Ministerial Decree against Ahmadiyah, is one of the most controversial policies regarding the freedom of religion in Indonesia. This joint decree was signed on June 9, 2008, by the Minister of Religious Affairs, Maftuh Basyuni, the Attorney General, Hendarman Supanji, and the Home Minister, Mardiyanto. This decree ordered Ahmadis to stop their religious activities, including spreading the teachings and beliefs that are considered deviant and misled.

\section{AHMADIYAH VS ORTODOX MUSLIMS}

The banning of Ahmadiyah through the issuance of SKB or Joint Ministerial Decrees cannot be separated from the orthodox Muslims' ongoing efforts, especially those of hard line or fundamentalist Islamic groups (Kelompok Islam Garis Keras), numbers of which have increased since the fall of Soeharto's New Order Regime in 1998.

During the Soeharto era, the hard line Islamic groups had been marginalized and oppressed because they were considered threatening the Pancasila and the unity of Indonesia by implementing the Islamic law (Syari'ah) and calling for the establishment of an Islamic state. Their movements were restricted, as they were associated with fundamentalist Islamic groups in other countries, such as Hizbut Tahrir in Egypt and Taliban in Afghanistan.

TEOLOGIA, VOLUME 23, NOMOR 1, JANUARI 2012 
After the resignation of Soeharto, it seems that there was euphoria about the new freedom because, in the Suharto era, freedom of expression had been limited due to the way Suharto used his power, which was very repressive and authoritarian. After Soeharto resigned, fundamentalists have used the transitional periods after him, known as the reformation era (era reformasi), to establish various groups which aim at fighting immoral acts and social illnesses in society, such as gambling, drugs, and prostitution.

Furthermore, the hard line Islamic groups believe that Islam is the only way to achieve salvation. As a result, they will not tolerate any efforts to convert Muslims to other religions. As they view Ahmadiyah as not being part of Islam, they took action by persecuting Ahmadiyah and destroying its assets when they knew that a lot of Muslims had joined Ahmadiyah. In addition, Barker (The Jakarta Post, 2008) argues that, perhaps, because of the rapid development of Ahmadiyah, which comprises 242 branch offices throughout Indonesia, this has threatened the existence of other Islamic groups, especially the hard line Islamic groups. As a result, they started to take action.

Another characteristic differentiating the hard line Islamic groups from other Islamic groups, especially the moderate ones, is the fact that in terms of understanding Islamic religious texts (especially the Qur'an and Hadith), they tend to understand these literally and textually rather than understanding them contextually. For moderate Muslims, when interpreting and understanding the Qur'an, it is necessary to distinguish between normative and contextual verses of the Qur'an. The normative aspects of the Qur'an are the verses which are universal and their applicability does not change at all times and circumstances, while the contextual aspects, on the contrary, have specificity in terms of cultural and social contexts, which might change in accordance with the contexts of time and circumstances. According to Niaz A. Shah, ${ }^{11}$ the context consists of three aspects: historical context; social context; and the Qur'anic context, which has two meanings firstly, when and why a verse is revealed, and secondly, what is the overall Qur'anic approach to the right to freedom as religion.

Another Muslim thinker argues that all Qur'anic verses were revealed within a specific time, history, context and circumstance. So, it is necessary for Muslims with other circumstances to interpret those verses according to their new circumstance. However, the way they interpret those verses must refer to the original message or substance of those verses. For example, in the attempt to understand the Qur'anic concept of Jihad, a moderate Muslim interpretation is close to the Ahmadiyah concept, which understands it in the 
sense of spreading Islam by peaceful persuasion. They argue that it is necessary to understand it from its specific context. This means that aggression, war and other forms of physical violence are no longer appropriate to apply in the peaceful world of the present time that involves the enforcement of human rights. In contrast, the hard line or fundamentalist Muslims tend to understand it literally: Jihad is merely understood as a war against the infidels and evils. In terms of the Ahmadiyah sect, the fundamentalist Muslims view Ahmadiyah as being involved in apostasy and blasphemy. These are regarded as evils that must be prevented and stopped. This shows that the definition of infidel is also vague, as someone or a group might be accused as infidel by others who have different views or opinions. As a result, the hard line Islamic groups might believe that attacking other Muslims because they have different opinions is allowed. It seems here that the monopoly of truth is not only found in intra-religion, but also in interreligion (The Jakarta Post 2008).

As has been explained in this chapter, the hard line Islamic groups' actions to "wipe out" the Ahmadiyah finds support in the fatwa issued by the MUI as one of the representatives of orthodox Islamic religious leaders in Indonesia. This was based on the perception that Ahmadis were deviating from Islamic teaching, thus it must be outlawed. In this regard, Gillespie ${ }^{12}$ argues that this is one of the most controversial fatwa, for it labeled the Ahmadiyah, a group that had existed peacefully in Indonesia for over 60 years, as 'outside Islam'.

Based on the discussion in this chapter, it is obvious that there has been a long conflict between Ahmadiyah and the orthodox Islamic groups since Ahmadiyah has been internationally announced as heretical through a recommendation made by the World Muslim League, followed by the fatwa issued by the local Muslim leaders association. The implications of these recommendation and the fatwa have led to an ongoing persecution of Ahmadiyah globally and nationally. In Indonesia, the persecution has taken various forms, such as intimidation, threat, and even physical attacks against Ahmadis and their properties. To resolve these problems, the next chapter will discuss and analyze this persecution case from a human rights law perspective, both nationally and internationally. Non-judicial approaches will be offered as well as an alternative way of dealing with the problem.

Cases of persecution against Jemaat Ahmadiyah Indonesia as a minority group have been increasing since 2005, when Majelis Ulama Indonesian (Indonesia's Council of Islamic Clerics) issued a fatwa (religious opinion). Ahmadis were seen to be deviating from Islamic teaching, 
especially regarding the doctrine of khatam al-nubuwwa (the finality of prophethood), which means that the Prophet Muhammad is the last prophet and there is no prophet after him. ${ }^{13}$ In relation to this doctrine, Ahmadis believe that the prophethood is not final, but still continues. This belief is based on their interpretation on the doctrine of khatam al-nubuwwa, which refers to the superior quality of Muhammad's prophethood rather than its finality. Therefore, they argue that the appearance of other prophets after Muhammad is possible. It is obvious that this belief is in opposition to the mainstream belief of orthodox Islam. That is why orthodox Muslims issued a fatwa declaring that Ahmadiyah is heretical. Following this fatwa, several Islamic groups attacked Ahmadiyah centers, including attacks in Bogor, Lombok Timur, Garut, Tasikmalaya, Parung, and other areas of Indonesia. The attacks in Lombok Timur, Nusa Tenggara Barat continued until 2006, forcing hundreds of Ahmadis to be refugees as their houses and mosques were destroyed by marauding masses. Because they felt insecure, some Ahmadis asked for asylum at the consulates of Australia and Germany in Denpasar, Bali (The Jakarta Post 2006).

\section{PEACEFUL APPROACHES TO PREVENT RELIGIOUS PERSECUTION}

Most people might consider that judicial strategies are the only ways of combating religious persecution. However, they should also take into account the non-judicial strategies that are aimed at preventing human rights violations, especially regarding religious persecution and discrimination. There are two strategies that will be discussed here - firstly, intra-religious dialogue and secondly, multicultural and human rights education. Both strategies are important and need to be taken into account to eradicate human rights violations and to raise people's awareness of human rights values. This is consistent with the approach advocated by the UN SecretaryGeneral and UNESCO Director-General to promote religious and cultural understanding, harmony and cooperation. They argue in favour of three points: firstly, the use of education as a way to promote sustainable tolerance and peace; secondly, an overview of the activities designed to promote interreligious dialogue; and thirdly, the implementation of activities to support dialogue among civilizations.

\section{Intra-religious Dialogue}

Another important strategy that can be used to eradicate religious 
persecution is both inter-religious and intra-religious dialogue. Why both? Because of the fact that religious persecution does not only occur between two different religions or more, but also occurs within one religion or belief, such as between Ahmadiyah and Orthodox groups within Islam.

In fact, inter-religious dialogue is more popular than intra-religious dialogue. This is because conflict and persecution, on the basis of different religions and beliefs, commonly occurs worldwide, rather than internal conflicts within a religion. As a result, not many people pay attention to the phenomenon of internal persecution. They might argue that internal persecution is not as dangerous as external persecution. However, the escalation of internal persecution has been overlooked since religious persecution is understood more as inter-religious persecution rather than intra-religious persecution. That is why it is essential to note that intra-religious dialogue is as important as inter-religious dialogue as has been mentioned by Abdel Fattah Amor (1994) in his report:

The establishment of interdenominational dialogue dialog the main religions and beliefs is of the utmost importance in combating the injurious effects of the sectarian ideas and intransigence demonstrated by certain extremist groups and enhancing religious tolerance throughout the world.

Because international human rights standards apply equally to violations resulting from both inter and intra-religious persecution, human rights activists should start paying equal attention to both forms of religious persecution. In terms of intra-religious dialogue, there is no difference between this and inter-religious dialogue: both have similar principles. The second and third point of the UN Secretary-General's note, which is mentioned above for example, mentions the importance of activities designed to promote inter-religious dialogue, which includes intra-religious dialogue, and their implementation to support dialogue among civilizations. It can be concluded that meaning of inter-religious dialogue here implies both dialogue among religions and within a single religion.

As there is no significant difference in both inter-religious and intrareligious dialogues, so the interfaith dialogue principles can be simply applied to intra-religious dialogue. There are a number of principles on how to conduct interreligious or interfaith dialogues. Groff, ${ }^{14}$ for example, formulates a number of interfaith dialogue principles, such as: (1) Be open and willing to listen; (2) Do not try to convert anyone from their religion to yours; (3) Do not try to create one world religion, but respect the diversity of traditions; (4) Let people from each religion speak for themselves, from their 
own experience, about what it means to practice that religion; (5) Allow the possibility of some common spirituality that underlies all the diversity of the religions through which that spirituality expresses itself; (6) Realize that one can enrich one's own spiritual-religious life by being open to learning from other traditions without having to leave one's own tradition.Realize that human beings - throughout the pre-recorded and recorded history, in different cultures and civilizations around the world - have sought to reflect on the deeper meaning and purpose of life, to honor the unknown and mysterious, and to connect to something spiritual and eternal beyond this transient material world and life.

The above principles are very practical. However, they require openness and honesty from those involved in the dialogue. It is also important to note that the final purpose of dialogue is not to determine whether a religion or belief is true or heretical, but to build understanding among the participants of the dialogue. Some people might misunderstand dialogue as debate. If so, the dialogue will be a part of the problem rather than a solution to the problem.

Regarding the Ahmadiyah case, the main problem lies in its doctrinal aspects, which are distinctly different to the mainstream teaching of orthodox Muslims. In this context, intra-religious dialogue is aimed at understanding the doctrinal differences between Ahmadiyah and orthodox Muslims and the reason for the differences. This is important, as many Muslims do not understand the facts and realities about Ahmadiyah and its doctrinal aspects.

Ideally, there should be an individual or group mediating the process of intra-religious dialogue between Ahmadiyah and orthodox Muslims in Indonesia. In this context, the Indonesian government through the Department of Religious Affairs (Departemen Agama) or the Indonesian Council of Ulama (Majelis Ulama Indonesia) could facilitate it. However, the government's response to the tension and conflict between Ahmadiyah and orthodox Muslim has been confusing and inconsistent. ${ }^{15}$ Furthermore, rather than becoming mediators for resolving the conflict between Ahmadiyah and orthodox Muslims, both the government and the Indonesian Council of Ulama are part of the problem by persecuting Ahmadiyah through the Joint Ministerial Decree and fatwa.

In this context, the roles of human rights and non-government organizations activists are very significant to initiating the intra-religious dialogues between Ahmadis and orthodox Muslims in order to build understanding among them. However, one thing that the intra-religious 
dialogue facilitators should anticipate is the form of dialogue, which tends to be exclusive. It means that it is practiced only by the leaders or elites of religious communities, rather than people involved at the grassroots level (followers). In fact, those who live at the grassroots level understand more about the real situation in their communities, and that they know more about how to communicate the message or results of dialogue to their own communities. In addition, it seems that the participants of dialogue are those who already have a sufficient understanding of the problem. This is because they are educated people who have better access to media and information. As a result, the dialogue tends to be a place to affirm each other's ideas rather than becoming a place for strengthening the solidarity and unity in diversity. A successful intra-religious dialogue will lead to a new understanding of the differences and diversities. The focus should be on mutual respect as these differences are realities that cannot be rejected. Furthermore, an ideal intra-religious dialogue should refer to Bruinessen's concept of inter-religious dialogue, which involves interaction among different religious communities, both at a practical and intimate level. ${ }^{16}$

\section{Multicultural and Human Rights Education}

Before more discussion about the role of human rights and multicultural education in raising people's consciousness about the importance of human rights, it is important to note that the United Nations, as the main organization to promote and enforce human rights, does not only focus on judicial approaches to combating religious persecution, but also pays attention to non-judicial strategies, such as education. This can be seen from the results of the United Nations International Consultative Conference on School Education in Relation to Freedom of Religion and Belief, Tolerance and Non-discrimination. The result of this conference underlines the importance of promoting religious tolerance and belief through education aimed at protecting and respecting religion and belief in order to strengthen peace, understanding, and tolerance among individuals, groups, and nations, and with a view to developing a respect for pluralism. In addition it also encourages the role of government to promote and respect educational policies aimed at strengthening the promotion and protection of human rights, including eradicating prejudices and perceptions incompatible with freedom of religion and belief. ${ }^{17}$

Based on the above points, it is important to consider the role of education, especially multicultural and human rights education, as one of the 
ways to reduce human rights violations:

Human rights education is about acquiring not only knowledge but also skills and the ability to apply them; it is about developing values, attitudes and behaviour that uphold human rights but also about taking action to defend and promote them. It involves learning about human rights through the practice of human rights. (Excerpt from speech made by Mr Koïchiro Matsuura, Director-General of UNESCO, on the occasion of Human Rights Day, 10 December 2004).

Through multicultural and human rights education, students are taught how to respect others coming from different backgrounds from their own, which includes differences and diversities in aspects of religion or beliefs, culture, language, race, ethnicity, and so on. Prejudicial and intolerant thinking is the greatest challenge faced by educators of multicultural and human rights in formal schools as well as in society generally. Another challenge that educators and human rights activists must face is the fact that prejudicial and intolerant attitudes may have in fact been maintained by educational and religious institutions precisely through religious education.

In other words, prejudice and intolerance in a community is so often the result of socialization through educational media. It is more obvious when an educational system is influenced by religious dogma, such as religious education. The understanding of religious dogma in a religious community is transferred and socialized to other community members and the younger generation through religious education. If the understanding of religious dogma constitutes prejudice and intolerance to others in the religious community, the education (religious education) will maintain prejudice and intolerance, which is incompatible with the spirit of multiculturalism and pluralism. Rather than appreciating and supporting multiculturalism and respecting multi-faith, this model of education will lead to social segregation as well as increase sectarian conflict.

Regarding this problem, it is necessary to push for the formulation and implementation of paradigms, approaches and methods of education that will lead to a greater appreciation of respect for religious and cultural diversity. This model of education will reduce the intolerance and conflict in both inter-religious and intra-religious relations. It will develop the idea of social life based on just and peaceful principles. Thus, one of the main roles of contemporary religious education is to develop and maintain tolerance and inclusive attitudes among students, so they will be able to appreciate difference and diversity. 
Thus, in this context, both religious and educational institutions have an important role in forming the societies' characteristics (religious communities and students). Through education and teaching activities, they teach and transmit their specific cultures to their communities and students, such as values, attitudes, roles, and models of conduct. Here, both religious and educational institutions can use their specific cultures, including morality and ethics, to take a part in promoting the values of democracy and civility by arguing that these values are integral parts of their cultures. Some important values include appreciating different views and opinions, respecting the human rights of others, resolving problems without violence, respecting all forms of diversities, and obeying laws. Regarding the importance of tolerance and inclusive attitudes, these values should be viewed as the integral part of cultures, morality and ethics developed by both religious and educational institutions. Without this, it seems that the classical issues regarding the debates of incompatibility between religions (supported by religious education) and the values of democracy and human rights will never end.

In addition, it is important to note that one of the conditions for the realization of harmony and better relationships among different religious groups is by challenging stereotypes and prejudices about others. Here, religious and educational institutions can take a role in reducing intergroup prejudices by applying religious and educational activities that value pluralism and multiculturalism. In this regard, UNESCO declares that the main function of education is not only limited to learning to know, learning to do and learning to be, but also about learning to live together. This means that, ideally, education should teach all members of society how to appreciate diversity and provide them with the ability to live together peacefully with others.

In the Indonesian context, which constitutes a multicultural society, pluralism and multicultural education is necessary. Otherwise, social conflicts and national disintegration will always be a threat from time to time. The first strategic agenda must be to realize this by changing the existing paradigm for viewing differences and cultural diversity. This paradigm change needs to be especially applied to religious institutions and the educational system. In addition, pluralist and multiculturalist discourses should be developed in accordance with the Indonesian national motto, called "Bhinneka Tunggal Ika" (unity in diversity). This motto is very important for all Indonesians, as this describes the social, cultural and geographical realities of Indonesia, which consists of different cultures, 
languages, ethnics, tribes, customs, and so on. The motto "Bhinneka Tunggal I $\mathrm{ka}$ " sounds very democratic; however, it has been used by Soeharto's military regime to mean control, forced uniformity, and uncritical acceptance of government policies by Soeharto's policy known as SARA, which stands for Suku (ethnicity), Agama (religion), Ras (race), and Antar Golongan (intergroup relations).

In other words, the educational system in Indonesia has been misused and politicized by various regimes for pragmatic-political interests, since the Soeharo's New Order regime up to present day. Such manipulation does not only happen in Indonesia, but also occurs in other countries controlled by authoritarian regimes. It seems that such regimes understand that education is one of the most effective ways to socialize and internalize values from generation to generation. As a result, educational practices tend to follow such regimes' agendas rather than idealistic educational agendas simply because most of the financial support is provided by the regimes. As a result, it follows that the ideological underpinning of education parallels the states' ideologies. This implies that the effort to transform educational ideology is very complicated as changing an ideology involves changing a regime as well. To understand the relationship between education and regime in the Indonesian, Kraince has asserted:

...Indonesia's failure to deal with the violence and intolerance refers to serious problems within its legal and security sectors. However, the inability of Indonesian civil society groups to effectively counter expressions of religious intolerance points to problems in education. While analyses of the former regimes' educational failures are helpful to understand the problem, the question remains as to what role colleges and universities can play in supporting the development of a more tolerant and inclusive society. ${ }^{18}$

To challenge the authoritarian model of education created by former authoritarian regimes to maintain their status quo, it is necessary to propose a more humanistic model of education in which the aim is to liberate people from all forms of oppression. This model of education is typified by Paulo Freire's liberationist concept of education. According to Dananjaya, ${ }^{19}$ Freire's concept of education for freedom refers to actions for change. This idea is based on the view that the final stage of human cognitive is critical consciousness. Furthermore, he argue that, in terms of human rights education, the ultimate human cognitive development does not end at human rights consciousness, more than that, it is able to critically view the realities of human rights violations. As a result, he/she will change those 
violations to be human rights protections. In other words, what is needed today is a model of education that emphasises the spirit and values of democracy, participation, and humanism, which appreciate the realities of pluralism and multiculturalism. This model of education will create more opportunities for students to be creative, critical and open-minded, as it requires freedom of any aspects. More importantly, it requires a situation where students can be involved with others from different social, cultural, and religious backgrounds from their own. Having been involved in such situations with various social and cultural activities in schools, and living together with friends who have different perspectives from their own, students will learn from this process about how to appreciate differences and diversities, including religious diversities.

The above approaches to a more humanistic education should be introduced into the Indonesian educational system, including the religious education system. The purpose is to provide students with the basic ideas and understandings of how to live together in a pluralistic society like Indonesia, which consists of different religious and cultural backgrounds. Through these approaches, students will also be taught about the fundamental values of human rights that must be protected without discrimination, including the right to freedom of religion. If multicultural and human rights education can be introduced to the children and students as early as possible, either in formal schools or communities, the cases of religious persecution in Indonesia can be reduced in the future.

\section{CONCLUSION}

As a global phenomenon, religious persecution might occur within every religion as well as nation. In Indonesia, this phenomenon occurs within Islam, which is embraced by the majority of Indonesians. One of the most controversial cases regarding religious persecution is the discrimination experienced by Ahmadiyah, one of the minority Muslim groups in Indonesia.

Besides the judicial approaches, the non-judicial approaches should also be used as a alternative strategy, which aims at eradicating religious persecution experienced by Ahmadis by raising people's consciousness about human rights. This includes human rights education and intrareligious dialogue. In terms of dialogue, this research suggests the use of intra-religious dialogue between Ahmadiyah and orthodox Muslims. Both education and dialogue have also been recommended by the UN Human

TEOLOGIA, VOLUME 23, NOMOR 1, JANUARI 2012 
Rights Commission through the Special Rapporteur on freedom of religion.

The role of NGOs and human rights activists is pivotal in realizing those strategies. This research has found that they are needed to help Ahmadis restore their civil and constitutional rights as part of the Indonesian community who have the equal rights with all Indonesians. Thus, they must be treated equally before the law. Besides legal, educational and dialogical approaches, human rights activists may also be able to play an advocacy role to assist minority groups get back their rights. In addition, both preventive and curative approaches should be deployed to prevent or eliminate or to stop religious discrimination and other forms of violence based on religion.[]

\section{Catatan Akhir}

*Ahmad Afnan Anshori, M.A., MHumRightsEd. is a lecturer of Ushuluddin Faculty of IAIN Walisongo, Semarang. He obtained M.A. from the Center for Religious and Cross-Cultural Studies (CRCS) of Gadjah Mada University, Yogyakarta and MHumRigtsEd. from the Center for Human Rights Education of Curtin University of Technology, Perth Australia.

${ }^{1}$ See Marshal in David R. Hodge, "Advocating for the forgotten human right: Article 18 of the Universal Declaration of Human Rights - religious freedom" in International Social Work, 2006 p. 432.

${ }^{2}$ Mohamed SM Eltayeb, A Human Rights Approach to Combating Religious Persecution: Cases from Pakistan, Saudi Arabia and Sudan, (Oxford: Intersentia, 2001), p. 30.

${ }^{3}$ Ibid, p. 9

${ }^{4}$ Ibid, p. 63

${ }^{5}$ Munawar Ahmad, Faith and Violence: The Islamic sect Ahmadiyah has been under official pressure and violent attack. Retrieved on 9 December 2008 from http://insideindonesia.org/content/view/14/29/

6 Sadia Saeed, Pakistani Nationalism and the State Marginalisation of the Ahmadiyya Community in Pakistan. (Studies in Ethnicity and Nationalism, ASEN Conference Special: Vol. 7, No. 3, 2007), p. 135

${ }^{7}$ Eltayeb, A Human Rights, pp. 67-68

${ }^{8}$ Emmanuel Sivan, The Holy War Tradition in Islam. Religion in World Affairs (Orbis, 1998), p. 175

9 The 1974 Declaration by World Muslim League stated that all the Muslim organizations in the world must be aware of all the activities of Qadianis in their respective countries. Moreover the Muslims of the world must be shown the picture of Qadianism and be briefed on their various tactics so that the Muslims of the world can be safe from their design. All the Muslim countries must impose restrictions on the activities of the claimant of Prophethood Mirza Ghulam Ahmad Qadiani's followers; must declare 
them a non-Muslim minority and must not trust them with any post of responsibility in any Muslim country. See also Alfitri, "Religious Liberty in Indonesia and the Rights of "Deviant" Sects" in Asian Journal of Comparative Law, Volume 3, Issue 1 2008, p. 20

${ }^{10} \mathrm{Ibid}$, p. 21

${ }^{11}$ Niaz A Shah, "Freedom of Religion: Koranic and Human Rights Perspectives" in Asia-Pacific Journal on Human Rights and the Law, 1 \& 2, 2005, p. 70

${ }^{12}$ Piers Gillespie, "Current Issues in Indonesian Islam: Analyzing the 2005 Council of Indonesian Ulama Fatwa No. 7 Opposing Pluralism Liberalism and Secularism" in Journal of Islamic Studies, Oxford University Press, 2007, p. 219

${ }^{13}$ Eltayeb..., p. 66

14 L Groff, Intercultural communication, interreligious dialogue, and peace. (Elsevier Science Ltd, 2002), pp. 709-710

${ }^{15}$ Alfitri, Religious Liberty, p. 21

${ }^{16}$ Bruinessen, Martin van. Islamic State or State Islam? Fifty Years on StateIslam Relation in Indonesia. Retrieved on 3 November 2008 from http://www.let.uu.nl/ Martin.vanBruinessen/personal/publications/State-Islam.htm.

17 Edd Doerr, A groundbreaking declaration. The Humanist; Mar/Apr; 62, 2; Academic Research Library, 2002, p. 42

${ }^{18}$ Richard G Kraince, Islamic higher education and social cohesion in Indonesia. (UNESCO IBE, 2008), p. 348

${ }^{19}$ Dananjaya, Utomo, Pendidikan Hak-Hak Asazi Manusia dengan Pendekatan Multikultural, 2008, p. 8. Retrieved on 7 December 2008 from http://fahdamjad.files.wordpress.com/2007/09/pendidikan-ham.pdf 


\section{DAFTAR PUSTAKA}

Ahmad, Munawar, Faith and Violence: The Islamic sect Ahmadiyah has been under official pressure and violent attack. Retrieved on 9 December 2008 from http://insideindonesia.org/ content/view/14/29/

Alfitri (2008) Religious Liberty in Indonesia and the Rights of "Deviant" Sects. Asian Journal of Comparative Law Volume 3, Issue 1

Bruinessen, Martin van. Islamic State or State Islam? Fifty Years on State-Islam Relation in Indonesia. Retrieved on 3 November 2008 from http://www.let.uu.nl/ Martin.vanBruinessen/personal/publications/ State-Islam.htm.

Dananjaya, Utomo (2001) Pendidikan Hak-Hak Asazi Manusia dengan Pendekatan Multikultural. Retrieved on 7 December 2008 from http://fahdamjad.files.wordpress.com/2007/09/pendidikan-ham.pdf

Doerr, Edd, A groundbreaking declaration. The Humanist; Mar/Apr; 62, 2, 2002; Academic Research Library. pg. 42

Eltayeb, Mohamed SM, A Human Rights Approach to Combating Religious Persecution: Cases from Pakistan, Saudi Arabia and Sudan, (Oxford, Intersentia, 2001)

Groff, L, Intercultural communication, interreligious dialogue, and peace, (Elsevier Science Ltd., 2002).

Saeed, Sadia (2207) Pakistani Nationalism and the State Marginalisation of the Ahmadiyya Community in Pakistan. Studies in Ethnicity and Nationalism, ASEN Conference Special: Vol. 7, No. 3, 2007

Shah, Niaz A, Freedom of Religion: "Koranic and Human Rights Perspectives." Asia-Pacific Journal on Human Rights and the Law, 1 \& 2, 2005: 69-88

Sivan, Emmanuel, The Holy War Tradition in Islam. Religion in World Affairs. Orbis, 1998.

Sodiq, Muhammad (2008) Jemaat Ahmadiyah Indonesia: Keyakinan yang Dihakimi. Paper presented at Seminar Nasional "Membangun Persatuan di Tengah Melemahnya Perlindungan Negara Terhadap Kebebasan Beragama Di Indonesia; Perspektif Khilafat Ahmadiyah" 
Tiboro, Siarma. Ahmadiyah worried about security. The Jakarta Post. Retrieved on 10 December 2008 from http://www.theper secution.org/world/indonesia/05/11/jp03.html

The Jakarta Post, December 14, 2008. Retrieved on 19 December 2008 from http://www.thejakartapost.com/news/2008/10/09/witnesstestimonies-favor-suspect-monas-attack.html

Zulkarnain, Iskandar (2008) Mencari Solusi Masalah Ahmadiyah Indonesia. Paper presented at Seminar Nasional " Membangun Persatuan di Tengah Melemahnya Perlindungan Negara Terhadap Kebebasan Beragama di Indonesia; Perspektif Khilafat Ahmadiyah".[] 